\title{
Why ShOuld PoOr PeOPle Get FREE LAWYERS?
}

\section{Duncan Webb*}

Many view pro bono work as charity and those who engage in it as somewhat saintly. In this article Duncan Webb argues that there is an ethical obligation on all practitioners to devote some of their time to pro bono work. In making this argument he distinguishes pro bono work from other free work such as public interest, self promotional, and contingency fee work. He also attempts to address some of the objections that are commonly raised against a claim that pro bono work is ethically obligatory. He concludes by suggesting ways in which pro bono work could be most effectively delivered.

\section{INTRODUCTION}

No one should be denied access to justice due to poverty. There are few who would deny such a proposition. The question this paper poses is to what extent the legal profession, and at a more personal level, each and every practitioner, has an obligation to ensure access to justice where impecuniosity would be an otherwise insurmountable barrier. Ought a lawyer, in some circumstances, work for nothing?

This paper asserts that a lawyer, or firm, has a moral duty to provide pro bono work. Moreover it is more than a duty to stay within certain minimum obligations, but rather part of the duty to foster a healthy profession. This is argued from the premise that in practicing law, lawyers are part of a system which they have a duty to uphold and promote. The paper then addresses some of the difficult problems of what amounts to a case deserving pro bono work, and makes some suggestions in respect of the practical difficulties of providing pro bono work.

\section{PRO BONO - FOR WHOSE GOOD}

It is important to be clear what is meant when we talk about pro bono work. The phrase pro bono publico (invariably abbreviated to pro bono) indicates that the service is tendered

* Senior Lecturer in Law, Victoria University of Wellington. 
"in the public good". 'Such a label may raise objections. The first objection that has been made is that the proffering of free legal services is not in the public good at all. Rather it is in the interest of the individual upon whom the benefit is directly conferred. That the individual recipient benefits is undeniably true. However, it is a misconception to conclude that because the individual benefits directly, the public does not also receive a benefit. Further, one of the most compelling reasons for a practitioner to provide free work is not the conferral of a benefit on any particular person, but rather the conferral of the benefit of legal services on members of a class of persons - those to whom access to justice would otherwise be denied - and consequently on society as a whole. Thus it is accurate to distinguish work undertaken without charge because the client simply cannot afford to pay from the situations where the indigent client has a special relationship with a member of the firm or some other ulterior reason exists for undertaking the work. ${ }^{2}$

The second objection to the use of the pro bono label arises where the lawyer undertakes work either because of the nature of the issue involved or because the work gives profile to the lawyer or the firm (or both). In the latter case the main beneficiary of the work is the lawyer themselves. It is, in effect, a kind of sponsorship where the lawyer manages to associate themselves with a particular, high profile piece of litigation which they anticipate will have considerable flow on effects. While it is not suggested that such conduct should be discouraged, it is not properly considered pro bono work. The motivating factor is the lawyer's self interest, and the provision of the services is not so much dependant on the need of the client as on the profile that bringing the case will give to the lawyer.

A more problematic class of cases is where the lawyer takes a case without charge because the issue involved is one upon which the lawyer has particularly strong views. Thus it may be well known that certain lawyers will take discrimination cases, or Waitangi Tribunal claims for low or no charge because of their own political beliefs. In some cases charitable organisations or interest groups may employ their own lawyers who will assume people's causes if they accord with the political stance of the organisation. Such lawyers have been called public interest lawyers because in many instances the political views that they support are considered to be beneficial to the public interest. While there is a sense in which the provision of such free legal services can be said to be in the public good, it is necessary to separate these from those cases where the only reason that the service is provided is because the client would not otherwise be able to enforce their rights. One compelling reason to distinguish the two is the political nature of the public interest lawyer.

1 For an analysis of the public element see J F Smurl "In the Public Interest: The Precedents and Standards of a Lawyer's Public Responsibility" (1978) 11 Ind L Rev 797, 801.

2 This kind of free legal work is examined in P R Lochner "The No Fee and Low Fee Legal Practice of Private Attorneys" (1975) 9 Law \& Society Rev 431. 
Consider the pacifist lawyer who defends anti-military protesters against disorderly conduct charges. Clearly there are two quite conflicting views as to whether such a protest in the public interest, and whether the actions of such protesters ought to be supported by the provision of free legal representation. Such lawyers are really providing free legal service in support of their own firmly held perceptions of what is in the public good, the view of which may vary wildly.

Let us confine our discussion of pro bono work to those cases where the motivating factor is the fact that poor people would be unable to exercise their legal rights if they had to pay for the service. In particular providing legal services will not be pro bono work where it is motivated by self promotion, special relationships or political standpoint. It is important to keep these different reasons for providing free legal services distinct because the arguments in respect of the provisions of such services differ significantly.

Work undertaken on a contingency fee basis cannot be regarded as pro bono work when the case is unsuccessful. In a contingency situation a client promises to pay a fee provided that the case is successful. This is not free legal work. It is fatuous to look at the facts of such a case after the matter has been tried and lost and say that there was no cost to the litigant and no benefit to the lawyer. The question needs to be addressed at the lime the lawyer is retained. The cost to the client is the loss of a proportion of the possible proceeds of the case, the lawyer receives a corresponding benefit.

In other respects we need to have a broad, though not unlimited, conception of what amounts to pro bono work. It is not just the traditional kind of legal advice and advocacy that will amount to pro bono work. There are numerous ways in which members of the profession can give their time to assist in access to justice for poorer members of the community. If we accept that pro bono work is work that assists poor people in exercising their legal rights it is clear that this may take a number of forms. Legal education is one example. Much of the failure to exercise rights is attributable to an ignorance of either the rights themselves, or the process by which they may be enforced. By educating those sectors of the population who most need it, self help becomes possible. Further, if there is an adequate level of education it is likely that the kind of situations which need advocacy are less likely to arise. If it is clear that a person knows their rights others are far less likely to ignore them. However, one must be careful not to go too far. Work can only properly be considered pro bono if it is both in the public good and the work requires the exercise of skill as a lawyer. Thus being a committee member of the symphony orchestra, or on the board of trustees of the local school are not of themselves pro bono activities. ${ }^{3}$

3 Some lawyers are recorded as claiming positions held on symphonies, orchestras, opera associations, and even baseball umpiring as pro bono work! See F Marks, F Leswing, and B 


\section{PROFESSIONAL CONDUCT: ASPIRATION OR REGULATION?}

Many academics, it can be argued, teach law as if it was being examined through the eyes of a bad person who was concerned mainly with staying within the law, but as close to the boundaries as possible. The legal profession arguably suffers from the same defect. The law governing the duties of lawyers to the court and their clients is understandably concerned with the obligations and duties of lawyers. Less understandable is the similar stance taken by the Rules of Professional Conduct of the New Zealand Law Society which sets out minimum standards of conduct to which lawyers are to adhere if they are to avoid a disciplinary hearing. Those rules state in their introduction: ${ }^{4}$

It is reiterated therefore that this publication, to the extent possible defines the bounds within which a practitioner may practice the profession. Within those bounds the prime responsibility of a practitioner is his or her own sense of professional responsibility. The preservation of the integrity and reputation of the profession is very much a matter for individual members.

This appears to be at odds with the statutory functions which the Law Society is obliged to fulfil under s 4 of the Law Practitioners Act 1982 which provides

(1) The general functions of the Society shall be-

(b) To promote and encourage proper conduct among the members of the legal profession:...

(d) To preserve and maintain the integrity and status of the legal profession:

The Law Society may therefore be criticised for having abdicated its responsibility to "promote proper conduct" and "preserve the integrity of the profession". It is of note that this is quite distinct from the suppression of "illegal, dishonourable, or improper practices by members of the legal profession" which is specifically dealt with in s 4(1)(c).

There are plenty of examples on which lawyers can model themselves if they want to be a successful lawyer. Works of fiction are replete with lawyers who act as zealous advocates for clients with morally tenuous claims, and for their loyalty are rewarded with astronomical fees. Moreover within the profession there is a continued focus on managing legal practices in a manner to maximise profits. As Justice Kirby stated: ${ }^{5}$

Fortinsky "The Lawyer, The Public and Professional Responsibility" (American Bar Foundation, Chicago, 1972).

4 New Zealand Law Society Rules of Professional Conduct for Barristers and Solicitors (4th ed, Wellington 1996) 4.

5 Hon M Kirby “Legal Professional Ethics in Times of Change” (1996) 14 Aust Bar Rev 20, 25. 
The practice of law is today a business where once it was a profession. Market capitalism has come to dominate the legal profession in a way that it did not a generation ago. Law firms whether in 1956 or 1996 have always had to turn a profit too if they were to staty in business. But today the profit motive seems to be writ large in a way it was not in the past.

There is, of course nothing wrong with seeking to run an efficient and profitable legal practice per se. The criticism is that this is the focus of the profession to the exclusion of nearly all else. ${ }^{6}$

The Law Society provides little or no consistent guidance on what kind of lawyer one ought to aspire to be. The predominant focus of ethics, both within and without the professional sphere has been "what am I prohibited from doing?" rather than "how ought I conduct myself?". It is worth noting that the American Bar Association Model Rules Professional Conduct, which is used in the majority of the American States, provides numerous provisions which offer guidance, as well as disciplinary provisions. This includes rule 6.1 which begins "A lawyer should aspire to render at least (50) hours of pro bono publico legal service per year"?

There are those who state that it does not take a university course to understand ethics. It is no doubt true that there is no great scholarship in comprehending that it is wrong to steal from clients. However, the objection misses the fact that proper professional conduct extends beyond the prohibitions on misconduct. ${ }^{8}$ To understand the kind of person a lawyer ought to be it is necessary to understand the problematic and pivotal role that the lawyer occupies in the legal system. A code which is solely prohibitory in its scope cannot properly be called a code of ethics at all. It is just a set of rules. ${ }^{9}$ The fact that the rules are not breached does not mean one is acting ethically - it just means one is not acting illegally.

6 Although the problem is not new - it was raised in "The Commercialisation of the Profession" (March 1895) The American Lawyer 84-85 cited in M S Galanter and T M Palay, "Large Law Firms and Professional Responsibility"; cited in R. Cranston (ed), Legal Ethics and Professional Responsibility (Oxford University Press, Oxford, 1995) 189, 190 complained that the legal profession was "contaminated with the spirit of commerce that looks primarily to the financial value and recompense of every undertaking".

7 The rule continues to indicate that the service should be provided without fee, or with a reduced fee. to persons of limited means, charitable, religious, civic community, government, educational organisations or civil rights and civil liberties organisations, however, there is no enforcement mechanism for the rule.

8 For a thorough and relevant discussion of professionalism see $\mathrm{R}$ Wasserstom "Lawyers as Professionals: Some Moral Issues" (1975) Human Rights 5.

9 This point is made by C Sampford in Law Ethics and Institutional Reform: Finding Philosophy, Displacing Ideology (1994) 3 Griffith LR 1. 
An "aspirational" approach to legal ethics might be criticised on the basis that it ought to be up to individual lawyers to decide what kind of conduct they will aspire to, and that it is not appropriate to interfere in the moral life of others. This objection, however, confuses the place of professional ethics with that of legal regulation. A profession is not a microcosm of modem society in which each member is at liberty to pursue self interest within the minimum constraints of law. Rather it a community of individuals on whom has been conferred the privilege of representing clients, and who have interests in common. ${ }^{10}$ It is legitimate and necessary in such a community to espouse and promote the kind of ethics that members ought to aspire to. A commitment to undertake pro bono work is a hallmark of a healthy and responsible profession. ${ }^{11}$

\section{WHY SHOULD POOR PEOPLE GET FREE LAWYERS ?}

\section{A Illusory rights}

The protection of the weaker members of society is widely considered to be an important role of the law in a developed state. This is often accomplished by placing duties on the more powerful members (such as businesses or government) and granting corresponding rights (to consumers or individuals). It is easy to congratulate ourselves on the protection of, say, consumers by pointing to the rights which have been accorded them against suppliers in respect of defective goods or services. ${ }^{12}$ However such rights are of no use unless they can be enforced and in most cases this means recourse to a tribunal or court. ${ }^{13}$ The fact is that the people who most need these rights are the least equipped to give effect to them. Rights are of no use unless and until they can be effectively enforced.

Access to the law may be difficult for some citizens at a more basic level than the enforcing of rights in a tribunal. Even matters such as making a will, or arranging access to a child will pose significant obstacles to some. Discussion of ethical matters often focuses on the role of advocacy, there is a more mundane but equally pressing way in which people are excluded from privileges by virtue of their lack of legal knowledge. Without legal advice the law is a foreign and hostile territory to many. This is particularly the case in respect of the poor. Unless such people receive advice and representation, the rights and privileges conferred by the law are hollow.

10 See D L Rhode "Ethical Perspectives on Legal Practice" (1985) 37 Stanf L Rev 589, 631 for a discussion of the tensions between the modern law firm and the concept of professionalism.

11 J Wade “Public Law Responsibilities of the Learned Professions" (1960) 21 La L L Rev 130, 131.

12 Examples are numerous and include the Consumer Guarantees Act 1993, Credit Contracts Act 1981, Hire Purchase Act 1971 and many more.

13 For further discussion see G Dal Pont Lawyers Professions Responsibility in Australia and New Zealand 75 (Law Book Company, North Ryde (NSW), 1996). 


\section{B Counterweight}

Even if it is possible for a poor person to pursue a dispute themselves, the contest will often be unequal. The need for advocacy is particularly apparent where there is a gross imbalance of power between parties. Consumer law and welfare law provide excellent examples. When faced with a bureaucratic structure the reflex of many people is to accept the "policy" of an organisation as equivalent to law. Even if it is known that the policy upon which decisions are made is contrary to law it will often be regarded as futile to try to enforce rights against such a large and apparently powerful organisation. The imbalance is particularly apparent in disputes between the government and the individual. While there may be an element of truth in that approach, the difficulties and non financial costs of enforcing such rights would be lessened significantly if reliable advice and advocacy was freely available.

Where one party is used to resolving disputes (as in the case of, say, an insurance company) there is an inherent imbalance when the other party is a first time disputant and has no knowledge of what to expect and what conduct is appropriate. Notwithstanding moves to alleviate this by mediation or the introduction of independent bodies such as the various ombudsman schemes, that imbalance cannot be redressed until the first time disputant is equipped with competent advocacy.

\section{Guide, tactician and friend}

Any advocate will bear witness that courts are generally generous to advocates in person. In some cases stretching rules of procedure to breaking point in an effort to overcoming the shortcomings of the litigants pleadings, or procedure. ${ }^{14}$ However, no degree of indulgence will assist the poor litigant in determining when and how to make and respond to the appropriate applications. While the various procedural applications that may be brought have a legitimate purpose, to the uninitiated they appear as stratagems designed by lawyers to prevent the speedy resolution of a dispute and trip up unsuspecting litigants. ${ }^{15}$

A litigant in person will likely be surprised by applications for security for costs, further and better particulars, striking out and so on. However, more detrimental is the fact

14 This argument is further developed in J R DeSteiguer "Mandatory Pro Bono: The Path to Equal Justice" (1989) 16 Pepp L Rev 355.

15 The use of stratagem in court proceeding is not new - nor is the championing of the cause of poor persons by an advocate. In M Millemann "Mandatory Pro Bono in Civil Cases: a Partial Answer to the Right Question" (1990) 49 Maryland L Rev 18, the case of Arbroath $v$ Saint Andrews (153233) where tenants of the Abbey of Saint Andrews were the subject of litigation over feudal dues. The court appointed a procurator to act as a pro bono advocate for the tenants. 
that it is unlikely that they will be aware of the procedural armoury available to them to best equip themselves for the trial proper. Further, there is more to court procedure than merely knowing of the existence of various pre trial applications that may be brought and how to bring them. Whether applications ought to be brought and the extent of the orders sought is very much a matter of strategy. One of the skills of an advocate is to know how to best prepare for a trial by using the pre-trial procedure. To compound this disability is the fact that such applications may be abused and used as mere stratagems to delay or cause expense to the other party. In short, even with the most able and self assured litigant in person, a trial without a competent advocate is a David and Goliath match.

\section{Champions of the adversarial method}

The adversarial trial method is very much a battle of words and minds. Most litigants, like those of old, employ the best champion they can afford to do battle for them. The adversarial system is predicated on the assumption that by a process of parties each proposing their own hypothesis and attacking the opposing hypothesis a just result will ensue. ${ }^{16}$ It is implicit in this assumption that each party is equally adept at pointing out the inadequacies of opposing arguments and highlighting the strengths of their own. To ensure that this is the case, in so far as it is possible, litigants employ professional advocates to argue their case. The advocates are effectively champions of the respective causes. It is obvious that if one party is unable to afford an advocate then by the very definition of the adversarial method their chance of success is considerably reduced.

\section{E Access to justice}

A brief survey of the ancient statutes still in force in New Zealand today demonstrates that the right of citizens to have unencumbered access to the courts is a fundamental tenet of our society. ${ }^{17}$ If there is no access to justice recourse may (arguably legitimately) be had to methods outside of the legal system, such as force or guile, to enforce the rights. ${ }^{18}$ John Locke

16 W H Simon "The Ideology of Advocacy: Procedural Justice and Professional Ethics" (1978) Wisc L Rev 30. See also above $n 10$.

17 Magna Carta 1297, 25 Edw. 1, cl 29: "We will sell to no man, we will not deny or defer to any man, either justice or right"; Statute of Westminster the First 1275, 3 Edw. 1, cl 1, "The King willeth and commandeth .... that common right be done to all, as well poor as rich, without respect of persons"; Observance of Due Process of Law Statute 1368, 42 Edw. 3, cl 3, "it is assented and accorded, for the good governance of the commons, that no man be put to answer without presentment before justices, or matter of record, or by due process and writ original, according to the old law of the land: and if any thing from henceforth be done to the contrary, it shall be void in the law, and holden for error". Also Petition of Right Statute 1627, 3 Cha. 1, cl 1.

18 For a full exposition of this view see D Luban Lawyers and Justice: and Ethical Study (Princeton University Press, Princeton, New Jersey, 1988) 237. The argument there is based on the contractarian tradition which can be traced to J Locke. 
was aware of the illusory nature of rights that could not practicably be enforced when he stated: ${ }^{19}$

[W] here an appeal to law, and constituted judges lies open, but the remedy is deny'd by the manifest perverting of justice,...to protect or indemnifie the violence or injuries of some men, or party of men, there it is hard to imagine anything but a State of War. For...it is still violence and injury, however colour'd with the Name, Pretences, or Forms of law.

Innovations such as the Disputes Tribunal and the legal aid scheme which operate in New Zealand demonstrate that we consider ourselves committed to improving access to justice wherever possible, however there are not sufficient to meet the need. It is part of the profession's wider responsibility to ensure that this need for access to justice is met. ${ }^{20}$ It is tempting to point out that any citizen can file a claim in court and have their dispute considered by the courts. This is, however, obviously too simplistic. It is tantamount to saying that even poor people have the right to eat at the Ritz. The fact is that many people, and especially poor people, simply do not have the means to bring their complaints before the courts. In particular they almost universally do not have the knowledge, expertise, confidence and emotional fortitude to pursue a claim to conclusion.

It is also too simplistic to claim that access to the courts means access to justice. Access to justice includes access to the rules which form the law. If it is practically impossible for a person to determine what their rights and obligations according to the law are, then those rights may as well not exist. Thus it is not simply the availability of court based dispute resolution procedures which are important to access to justice. It is also important that advice on the law in a non-litigious context be available.

\section{F Public interest}

Law is a public good. ${ }^{21}$ The fact that there is a system of rules which the State will enforce at the suit of a wronged party has large universal benefits. For example, aspects of law: give a basic framework in which economic exchanges can occur; provide a basis for recompense in the case of harm causing conduct; and it protect citizens from the dishonest or violent acts of others. This latter good is considered especially important. So much so that criminal conduct is prosecuted by the Crown and there is usually no need for the wronged

19 J Locke Second Treatise of Government ch XX, 322 (Oxford, Blackwell, 1976) 3rd ed, J W Gough ed.

20 See R Cranston "Ethics and Professional Responsibility" in Legal Ethics and Professional Responsibility R. Cranston (ed) (Clarendon Press, Oxford, 1995) 29.

21 This view has been criticised. The criticism is usually that while this may be the case in theory in practice the law confers only private benefit. It is this very problem which this paper seeks to address. See in particular S L Pepper "The Lawyers Amoral Ethical Role: A Defense, a Problem and some Possibilities" (1986) American Bar Foundation Research Journal 613, 618. 
party to petition the court that a perpetrator of a crime be punished. It is also of note that a comprehensive system of legal aid means that the need for pro bono work in the criminal sphere is negligible.

Although perhaps not quite as central to civic order, private law similarly confers a public benefit. Commerce generally operates efficiently and fairly because it is recognised that a disregard by one party to a transaction of their legal obligations would lead to litigation and the extraction of compensation. If it is apparent that one party to a transaction is, by virtue of poverty, unable to enforce their legal rights, one of the restraints on disregarding those rights has been removed. While this may not lead to a wholesale victimisation of poor people, it will lead (and arguably has led) to a greater degree of trammelling of the rights of the poor than the rights of people with the means to protect and enforce their rights.

At one level this is of concern only for the individuals involved. However, it also affects the costs of transacting for poor people, and consequently the amount of commerce which will occur. If a poor person is aware that if (for example) they purchase a car that turns out to be defective and in breach of contractual warranties which they are unlikely to be able to enforce, they are more likely to spend time and money establishing whether the car is defective prior to purchase to reduce the risk. The consequence is an increased cost which may well be beyond the means of those on whom it is imposed. Had they been confident that the right could have been enforced the costs of the transaction would have been lowered, and therefore it would have been more likely to occur - a public benefit.

At a more theoretical level, access to the courts is a necessary ingredient of the rule of law. It is central to the rule of law that society is ordered by clear rules, and that disputes are resolved by reference to those rules, and that the rules apply equally to all citizens. ${ }^{22}$ If legal advice and advocacy is not available to poor people, then neither are the courts open to them. If this inequality between citizens exists, the rule of law is in peril. ${ }^{23}$

\section{V “AM I MY BROTHER'S KEEPER?"24}

A lawyer might agree with all that has been said to date but consider that it really is no concern of theirs. After all, the comparison might be made that a builder may consider it a good thing if everyone has adequate housing - however that does not place an obligation on them to seek out those with inadequate housing and redress the inadequacy. Similarly, it

22 This is an important theme in H L A Hart The Concept of Law (Oxford University Press, Oxford, 1961).

23 M Millemann, above n 15, 71 .

24 Genesis Ch 4 v 9. 
could be argued, it is not a lawyer's job to provide free legal advice to those who cannot afford it, no matter how essential. ${ }^{25}$ There are, however a number of fundamental differences between both the services offered by a lawyer and many other service providers, and the person who provides that service. These will be considered in turn.

Linked to this objection is the argument that the provision of access to justice is a task that falls to government. To provide those services where government fails is to tacitly endorse, and give an excuse, to government for that failure. Understandably when a poor person comes to a lawyer and clearly cannot afford the cost of the work that is needed the first question is whether or not that person qualifies for legal aid. While legal aid goes some way to solving the problem of access to justice there are numerous reasons why it is not adequate by itself, or a substitute for pro bono work. Legal aid is payable only in respect of litigation, not the numerous other kinds of advice needed for poor people to take full advantage of the law. ${ }^{26}$ Further no grant will be made to groups of people (such as incorporated associations, unincorporated associations or charitable trusts). ${ }^{27}$ Legal aid will not be granted where the fruits of the litigation do not justify the costs incurred. ${ }^{28}$ Although provision is made for the non-financial fruits of litigation (such as, perhaps, the protection of civil rights) the implication seems to be that financial assistance to protect and enforce one's rights will not be forthcoming where the wrong claimed does not (in the eyes of the District Subcommittee) have any great impact. While it is undeniable that some litigation is frivolous, it is dangerous to deny the ability to enforce rights solely on the ground that they are "not worth it". What may be of little significance to most may, in the eyes of many poor litigants, be a large proportion of their wealth. A further difficulty with the existing legal aid scheme is that in may instances it operates as a bank which advances loans to litigants. By s 37 of the Act, civil litigants who receive legal aid will generally be required to make a contribution to the costs of litigation. ${ }^{29}$ Thus it can be seen that the Legal Services

25 This objection is traditionally rejected by pointing out that it is precisely this kind of public responsibility that distinguishes the legal profession from solely self serving businesses and justifies the special privileges to which lawyers are entitled. See R Pound The Lawyer from Antiquity to Modern Times (West Publishing, , Minnesota, 1953) 5. See also C Wolfram Modern Legal Ethics, (West Publishing, St. Paul, Minnesota, 1986) 950.

26 See ss 4 and 19 of the Legal Services Act 1991.

27 Above n 26, s 27. Limited exceptions are made for Maori litigants and Trustee corporations acting in a representative capacity.

28 Above n 26, s 34 (3)(e)(ii).

29 These are prescribed under rr 38 and 39 of the Legal Services Regulations 1991 and include a $\$ 50$ initial contribution along with a contribution based on disposable income and available capital. All of the claimant's disposable income over $\$ 2000$ per annum, and all of the claimant's disposable capital that is in excess of $\$ 2000$ will be payable as a contribution. 
Board which administers the legal aid scheme does not have the powers to meet the need for free legal services.

A further, and in one sense more fundamental, objection may also be based on the claim that there is no moral duty to provide that free advice. Indeed it may even be argued that there is a moral duty not to provide that advice. This may come in a number of forms. One might reject any suggestion that there is any meaningful moral duty other than to promote one's own interest - and giving free representation to others does not do that. Second, it could be argued that it is bad policy to provide free advice and representation to poor people. This, essentially utilitarian ground, is usually based on the objection that such a duty is impossible to administer. This may be due to the illusory nature of the concept of "poverty", the fact that this places those who fall just outside of the "poverty" category at a significant disadvantage, that it encourages litigation over relatively minor sums. Third, it is argued that to expect a lawyer to provide free work for poor people is a breach of fundamental rights of property and liberty. To require free work is, on this argument, a kind of enslavement, or at least enforced servility. Alternatively if the lawyers time is "money" then it is an involuntary transfer of wealth from the lawyer to the poor person.

The problem with these kinds of objections is the mistaken assumption that the role of pro bono work is the relief of the poor. While this is an incidental and beneficial effect, pro bono work is underpinned by a need to protect and promote the legal system.

\section{THE LAW'S KEEPER}

While there is no duty on a lawyer greater than that owed by any other member of society to assist a poor person per se, there is a significantly greater, and different, duty to promote and protect the legal system. This duty exists because a lawyer accepts the responsibilities of the system by participating in it and becoming an officer of the court. Becoming a lawyer is not like a royal grant of monopoly rights to profit from the practice of law. Rather it is entry into the institution of the courts with a licence to gain a from that institution, but with corresponding responsibilities. ${ }^{30}$ If one accepts that a lawyer does have a duty to maintain the integrity and workability of the legal system, and that the maximum possible access to the law is needed to maintain the system's workability, one must then accept that a lawyer has a duty to provide that access to those who cannot afford to pay.

One of the central aspects of the legal profession is its integrated character. The judicial system is comprised of not just the judiciary, but also counsel who appear before the courts

30 Rule 8.01 of the Rules of Professional Conduct for Barristers and Solicitors states that "In the interests of the administration of justice, the overriding duty of the practitioner acting in litigation is to the court or the tribunal concerned...." See above $\mathrm{n} 4$. 
and their instructing solicitors. By becoming a member of the profession lawyers obtain a number of privileges, one of the most important being the right to act as an advocate for others before the court. Historically senior members of the bar undertook, by oath, to pursue the causes of clients without delaying due to coveting money or profit. ${ }^{31}$ While some view the role of the lawyer as little more than that of an artisan others view the lawyer as an integral part of a system with a corresponding duty to maintain and uphold that system. Further, lawyers have, by their learning and their position, a monopoly on the provision of legal advice and services. Chief Justice Bruger expressed it thus: ${ }^{32}$

As a profession with a monopoly over the provision of certain services, we have special obligations to be energetic and imaginative in producing the best quality justice at the lowest possible costs for those who use it with a minimum delay.

\section{WHAT IS A DESERVING CASE?}

Linked with the question of what amounts to pro bono work is the question of what cases are deserving. It comes as no surprise to find that many, if not most, clients consider that they have a right to the law or the justice system, and that right ought not be impeded by the imposition of legal fees. There are a number of matters that need to be taken into consideration before the one can conclude whether or not the case in particular is a deserving one. This will include the degree of poverty, the merits of the claim, and the nature of the work involved.

\section{A The Illusoriness of the Poverty Line}

Those who can pay, but resent it, are not deserving of free legal services. This conclusion is reached on essentially economic/utilitarian grounds. There is a limited amount of free work that is or will be undertaken. To most efficiently utilise this limited resource it ought to be expended where the demand is greatest. Pro bono work ought to be bestowed on those to whom access to justice would be denied without it, not upon those who decline to retain a lawyer because, although they could afford it they have made a decision that the amount/likelihood of a benefit from such a move would outweigh the cost. The difficulty, however, is that this distinction is by no means clear.

It is commonplace to hear of people being below "the poverty line". Such an expression gives a false sense of certainty to the concept of poverty. One of the main objections to assistance directed to poor people is the imposition of a test as to what amounts to poverty.

31 J H Baker The Order of Serjeants at Law: A Chronicle of Creations, With Related Texts and a Historical Introduction, (Seldon Society, London, 1984) 88.

32 Hon W Burger "The Role of the Law School in the Teaching of Legal Ethics and Professional Responsibility" (1980) 29 Cleveland State L Rev 377, 378. 
Where a single line is drawn between the deserving and the undeserving the effect is to cause an injustice to those who only just cross the threshold into the "wealthy" class. By providing assistance to those defined as poor the barely wealthy are disadvantaged. This difficulty is reflected in the fact that many government assistance schemes (such as income supplements) are applied on a graduated scale. There is no poverty line, above which there is no need, and below which there is an absolute inability to obtain the necessaries of life. Rather there are varying degrees of need.

This ought to be reflected in the approach to pro bono work. There will be cases where the client is clearly unable to afford any part of the legal fees incurred. In terms of whether that person is poor enough, there will be no question. More difficult is the case where to bring the action, or retain the lawyer, while not entirely beyond the means of the poor person, will cause considerable hardship. In such a case it is suggested that an answer may be partially free legal work - that is the matching of the fee to the client's means. The proportions of assistance and contribution will be able to be matched to ensure that there is not an accidental disadvantaging of those in less than abject poverty. It should be noted that this does not mean that particularly wealthy clients should be charged more as they can afford it. This is an argument regarding relief from fees, not fee setting.

\section{B Right and Good - or Just Right}

Lawyers who undertake cases without charge who are defending admirable causes often get considerable attention. Those who do the same for causes which do not gain our admiration are sometimes scorned and even ostracised. When our mind is turned to what is a deserving case it usually leaps to consider whether the right claimed is one which is deserving of protection. Consider a situation where a journalist is being sued in defamation for roundly criticising a political figure and claiming that the politician has questionable morals. If one agrees with the opinions expressed and considers them justifiable, this appears to be a good reason for assisting the impoverished journalist by proving free services in the defence. Compare this with the neo-Nazi who is arrested on a pretence for a distasteful but peaceful demonstration which was airing views which most find repugnant. Many lawyers would find representing the members of such a group an unattractive proposition for full fees - and a ridiculous proposition to provide such services for free. There is a strong feeling that pro bono work is a kind of charity and therefore may be conferred on the causes one considers the most deserving.

There are a number of problems with the above approach. First, if the main motivation behind providing free legal services is access to justice then a political view of the case ought not come into consideration when determining what amounts to it being deserving. It is trite to say that people we disagree with, and even disdain, have as much right to representation as those we endorse and admire. Second, it is inaccurate to think that it is a matter of beneficence to provide free work. The provision of pro bono work is not like the 
bestowing of honours on those who meet our approval. It is more akin to the duty to act that one would have when we see someone in immediate distress - drowning is the traditional example. In such a case we have no excuse to decline to assist because if they had worn a life jacket they would not be in this trouble, or there predicament is only due to ignoring clear navigation signs. We have a moral (though not legal) duty to rescue simply because they have a pressing need, and we have the ability to alleviate that need. The duty on lawyers to provide pro bono work regardless of whether we agree with the poor person is even greater than in the example given. Lawyers are not idle bystanders who happen across the distressed individual. They are more akin to the harbour master whose reason for being is to ensure the safe passage of people through their waters.

\section{The Nature of Pro Bono Work}

So far the discussion of pro bono work has mainly been in terms of representation in litigation. This had been convenient, and accords with the broad conception of what pro bono work is. However this is a misconception and misleading. Access to justice is not synonymous with access to the courts. Even when the issue is a litigious one, it may be of a comparatively minor and mundane nature. In many cases when a person who is uneducated and lacks resources find themselves in legal difficulties they immediately assume themselves to be in the wrong, or that it is futile to enter into any disputation as they will surely come off worse than if they just submitted now. This may be in respect of matters as commonplace as consumer complaints, or traffic infringements. People of low income generally feel alienated in any situation where they come in contact with the law. In a sense they are on the other side of the law.

At an even more basic level there is a lack of knowledge in many cases as to the benefits of the law. While it is unlikely that poor people would set up companies, or create family trusts, there are still a number of aspects of the law which they could take advantage of but often do not through either their ignorance of the law, or their fear of the process. Thus things as commonplace as making a will, or jotting down the basic terms of a contract are too difficult and foreign for many people to undertake. Some of these kinds of tasks may be considered by lawyers as too trifling to concern them, and certainly were they to charge a reasonable fee for them the client would be losing money. This, however, is no good reason for not providing such a service. From the perspective of that indigent client the arranging of their meagre assets by will will be of immense importance to them. Similarly the disposal of an old jalopy on other than cash terms will be the sale of their largest asset on complex terms.

The disputes where pro bono assistance is most required are also generally mundane, at least to most lawyers. They will rarely be defamation suits of public figures, or civil rights claims. More frequently they will be claims against welfare agencies for underpayment, family disputes in respect of custody or access of children, complaints in respect of public 
health or education, consumer claims for defective goods or services or perhaps landlord tenant disputes. These are not the files that lawyers relish working on. They are often tedious, and to the lawyer, the benefits of success are negligible. However if these files are not undertaken for that reason it is tantamount to saying that only rights that have a significant value in our eyes are worth enforcing. Moreover for the perspective of the poor person the interests which are being protected or pursued often relate to fundamental matters such as housing, education, health and family etc which most take for granted. ${ }^{33}$

\section{WHO OUGHT TO UNDERTAKE PRO BONO WORK?}

When addressing the question of which lawyers ought to undertake pro bono work, it is usual to think of a lawyer who is, in some way, quite different from oneself. Common reasons why it would be thought inappropriate to undertake pro bono work are that the nature of the work is outside of one's area of expertise, that one's practice is far too busy to engage in further unpaid work, or that the practice makes little enough money as it is without diverting valuable time to non-paying clients.

Few of these excuses are persuasive. ${ }^{34}$ Take the practitioner who claims that their expertise is too narrow to really be comfortable helping out poor people, for example, a banking and finance practitioner. This claim of lack of skill or expertise is, however, not a persuasive excuse for a refusal to engage in pro bono work. As noted above much of the work is quite mundane and, to a moderately skilled lawyer, simple. The fact that there is a degree of learning involved in acquiring the necessary skills to undertake these tasks is not an insurmountable barrier. Indeed it can be viewed as indivisible from the work itself in the same way that keeping up with legal developments is part of any effective legal practice.

Further, there are very few lawyers whose skills are so narrow that they cannot contribute in some way to pro bono work. Such work is not restricted to advocacy, or strict legal practice. The purpose of pro bono work is to enhance access to the justice system, and in particular enhance it for poor people. There are a number of tasks of a legal nature which may not be directly acting for a poor person but nevertheless achieve such an object. These might include advising charitable bodies or other legal agencies such as community law centres, or undertaking an educative role informing poor people of the law and how to take advantage of it. When one considers the gross inadequacy of legal knowledge of many poor people, it is a weak reply indeed to say that one is not possessed of the precise kind of legal expertise required. It is possible to seek out the places in which one's expertise is best utilised, or if necessary engage in the lawyerly task of researching to extend one's expertise.

33 See M Millemann above n 23, 63.

34 This objection is scrutinised and rejected in M Millemann above n 23, 60 . 
In general legal practitioners are busy individuals. It is, therefore, not surprising that a common counter to the claim that more pro bono work ought to be undertaken is that the practitioner in question simply does not have the time. Such a response is premised on the assertion that those things which the practitioner does have time for are more important than doing pro bono work. Invariably the time in question is consumed by important (and paying) clients. It must be squarely admitted that the provision of pro bono work costs practitioners. The fact that if pro bono work were taken on paying clients would have to be turned away is no excuse for not undertaking pro bono work. Such work is not like giving small change to a charity - to be handed over if you have some lying around. It is a fundamental tenet of participation in the legal system. One other alternative for the busy practitioner is to retain another, less busy practitioner, to fulfil their pro bono obligations. While this may not be an ideal solution, it is a pragmatic response to the immediate problem. $^{35}$

A different response to the exhortation to undertake pro bono work is the complaint that, unlike many big city practitioners, many lawyers do not make a "fortune" and need to devote all their energies to eking a living out of their practice, and/or need to charge every client that comes in the door to cover basic overheads. ${ }^{36}$ This argument is particularly persuasive when we accept that many practitioners have spouses, children or other dependants who have a strong claim to any charity that is forthcoming. It is difficult to turn aside from paid work on any grounds, and when doing so puts a child's school fees in jeopardy or the like, the response is even stronger.

The main fallacy in this objection is that doing pro bono work is charity. Undertaking legal work at low or no cost is not some extra special duty that confers some kind of saintly quality on those who undertake it. Rather it is an obligation that is concomitant with the privilege of practicing law and being part of the institution of the justice system.

The other matter that it is necessary to be cautious about is the validity of the claim that engaging in pro bono work would cause real hardship to the lawyer concerned. It is undeniable that undertaking pro bono work may well reduce the possible income of a lawyer. If the lawyer is truly indigent and cannot themselves afford the necessaries of life, then there is no real ability to bestow a benefit on others if it reduces their own income. ${ }^{37}$ However, it is suggested that there are very few lawyers in such a situation. While claims

35 This issue is discussed in the text accompanying $n 45$.

36 The commentary to rule 6.1 of the ABA Model rules provides "Every lawyer, regardless of prominence or professional workload, has a responsibility to provide legal services to those unable to pay..." (ABA Centre for Professional Responsibility, Chicago, 1994).

37 J R DeSteiguer “Mandatory Pro Bono: The Path to Equal Justice” (1989) 16 Pepp L Rev 355, 373. 
that lawyers are universally rich are untrue, they are, compared to those in need of pro bono work, well off. This is particularly the case when one compares the means of most lawyers with those of the clients who most need the assistance of pro bono work. In such cases there is usually such a disparity that the claim that the lawyer cannot afford to undertake pro bono work is not sustainable.

\section{THE DANGERS OF PRO BONO WORK}

This paper has advocated that members of the profession are under an ethical though not legal obligation to undertake pro bono work. One of the tasks of the legal profession is to provide access to justice, and to even out the legal playing field between rich and poor. A significant danger is that the benefits of pro bono work will be conferred haphazardly without helping those who need it most. One of the difficulties of offering any benefit which seeks to assist the disadvantaged is the problem of people claiming the benefit which, while they may fit within formal criteria, are not a deserving case. In terms of pro bono work the danger is that vexatious litigants or other over zealous parties will inundate the lawyer who is available for pro bono work with requests while those really deserving cases will not have knowledge or gumption to come forward with a request for free legal advice.

One way to alleviate this is to make it widely known that free advice will be made: available to deserving cases. The obvious dilemma is that if one firm or lawyer were to do this alone they would be inundated with requests. Some coordination is needed in this regard. It is worth noting that in some of the larger US firms a partner is designated as the pro bono partner and deals with all such inquiries. This ensures that other members of the firm are not required to deal with such requests and that, at least within the firm, decisions as to whether to undertake free work are made consistently.

Ideally therefore the conferral of pro bono benefits would be coordinated centrally. In jurisdictions where pro bono work is more prominent, organisations exist which vet cases to ensure that the resources available are allocated according to need, that the problem is one which needs legal expertise, and to act as a buffer between undeserving litigants and the lawyers. ${ }^{38}$ To an extent this role is fulfilled in New Zealand by the Community Law Centres ${ }^{39}$ whose functions are: ${ }^{40}$

38 For example brief research shows that in New South Wales alone 37 organisations provide either co-ordination of pro bono work or some similar legal service.

39 Community Law Centres are established pursuant to s 154 of the Legal Services Act 1991 and are funded from the special fund of the District Law Societies which comes from the interest paid on trust accounts under s 91B of the Law Practitioners Act 1982.

40 Section 155 Legal Services Act 1991. 
[T] he provision of legal advice to the public or any section of the public, the provision of legal information to the public or any section of the public, the promotion of law-related education for the public or any section of the public, and such other functions as each community law centre considers necessary to ensure that the needs of the public that it serves for legal services are met.

Those centres are, however, scantily funded and exist only in major centres. There is, therefore, a need for coordination of pro bono work in New Zealand. This may be a role that the District Law Societies, or Community Law Centres could assume. Such a role will not, however, be needed until there is sufficient pro bono work being undertaken to warrant management of it.

A further objection which has been made to legal assistance for the poor is that it encourages inappropriate litigation on an already overburdened court system: ${ }^{41}$

Mr Bernard Shaw with his remarkable facility for putting things the wrong way round, had written that "the rich woman may terrorise the poor woman by threatening to go to law if her demands are not complied with". Transpose the words "rich" and "poor" and the truth is told. Very often the attitude taken up by the poor or insolvent plaintiff is near to blackmail: "If you don't pay me I will sue you, and that will cost you over 100 [pounds] anyhow"

Such an argument is easily dismissed. There is no suggestion that lawyers should take unmeritorious cases, and certainly should not take vexatious cases or cases predicated on blackmail. However, the mere fact that it will cost the defendant more to defend the claim than the amount claimed is no reason for not pursuing it. It simply indicates that our system is flawed if rights exist which cannot be economically enforced. In reality those rights are illusory. Further, the fact that the courts are busy is absolutely no reason to discourage poor litigants. Much court time is taken up by commercial interests pursing complex claims. To suggest that the system is too cluttered for poor people is to give the claims of the rich priority over those of the poor - a gross breach of the principle of equality before the law.

A further danger of pro bono work is that the legal assistance available to poor people is of an inferior quality. ${ }^{42}$ There is an economic argument that there is no incentive or benefit for a lawyer to do anything more than a satisfactory job if the client is not paying. Clearly where a client is paying, and is sophisticated, they will be critical of the performance of the lawyer. If it appears unsatisfactory they may, in extreme cases, change lawyers prior to trial, or in less extreme circumstances, not retain them again. Clients who are not paying for

41 C Mullins In Quest of Justice (John Murray, London, 1931) 390.

42 See Gilbert and Gorenfeld "The Constitution Should Protect Everyone - Even Lawyers" (1984) 12 Pepp L Rev 75. 
the work in the current environment, however, have little or no power to take their work elsewhere.

However the problem must not be overstated. There are a number of incentives other than the payment of a fee and return business of a client for a lawyer to perform well. These are the esteem of their colleagues and members of the judiciary, word of mouth amongst other prospective clients, and a personal pride in their profession. The profession of law is distinguished from other non professional occupations by the strong sense of collegiality which includes scrutiny of the conduct of other members of the profession. A further incentive is, of course, the Rules of Professional Conduct for Barristers and Solicitors which sets minimum standards of conduct in legal practice. A further protection in litigation against substandard advocacy is the duty of the barrister to the court. If an advocate is incompetent in the presentation or defence of a case they wrong not only their client but also the court to which they owe the primary a duty to serve. ${ }^{43}$

Even if it is accepted that the service provided on a pro bono basis will be "Morris Minor" rather than "Rolls Royce" service, this is a significant improvement on treading the treacherous legal path alone and on foot. Put less metaphorically, even a lawyer who meets only the bare requirement of competence, will increase a poor client's chance of enforcing their rights immeasurably. The fact that this kind of legal service is not of the quality to which we aspire is not a sufficient reason to deprive the poor person of it.

If pro bono work were coordinated properly it may be that some of the problems could be avoided. One of the main difficulties is the fact that, no matter how bad the service, there is no real ability for a pro bono client to "fire" their lawyer. ${ }^{44}$ To do so would mean abandoning the claim or processes that they are engaged in altogether. If pro bono work was coordinated centrally this problem could be largely alleviated. It would be possible for such an organisation to provide an alternative lawyer where one had proved unsatisfactory. Thus the rights of the claimant would not be dependant on the competence (and goodwill) of the lawyer. Another proposal is the use of vouchers of some kind which may be used at any of a number of lawyers. This enables greater choice by the client rather than reinforcing the beneficiary/benefactor type relationship that schemes which allocate lawyers may engender. Some schemes in the United States encourage busy practitioners to "buy" pro bono hours from other practitioners. The advantage of such a practice is that, although the client is not paying for the work, the lawyer is receiving remuneration and therefore is less likely

43 Rule 8.01 of the Rules of Professional Conduct for Barristers and Solicitors, see above $\mathrm{n} 4$.

44 It is also of note that the right of a client to transfer from one practitioner to another is central as is made apparent in r 6.05 of the Rules of Professional Conduct for Barristers and Solicitors,: "A client has an unequivocal right to change from one practitioner to another". See above $n 4$. 
to see the job as less important than other tasks. ${ }^{45}$ Other ways around the problem are to aggregate the pro bono commitments of a firm and allocate pro bono work to members of the firm who are less busy. The funding of organisations concerned with legal access for the poor by donation is also widely regarded as an acceptable substitute. ${ }^{46}$

\section{CONCLUSION}

The basic premise of this paper is uncontroversial - that people ought not be denied the benefits of the legal system and law because of poverty. The fact is that in New Zealand today there are many people who would avail themselves of the law and legal system and thereby improve their lot, but for the fact that they cannot afford a lawyer. I have argued that the duty to alleviate this problem falls at the feet of the profession. This is a distasteful conclusion. It runs counter to many prevalent views such as the right to the fruits of one's labour, and the freedom to sell one's labour in the open market. It also meets the objection that it is the task of government to supply the funds to meet such a need.

I have rejected these arguments on the basis that lawyering is distinct from other occupations in that it holds a monopoly on a fundamental element in the social ordering of a society subject to the rule of law - the ability to utilise and enforce the law. This privilege is not without costs. If one is to become part of the legal system, one must also be committed to the preservation and promotion of its values including access to the law.

There are also a number of more practical problems regarding the provision of pro bono work such as how to distinguish between a deserving and undeserving case, how to best utilise one's skill to assist poor people, and how to avoid the problem of habitual litigants availing themselves of free services. These problems can be largely dealt with by the central administration of the provision of pro bono work. The central regulation of the provision of pro bono work is necessary to deliver such services most efficiently. Organisations, such as Community Law Centres, already exist which are capable of undertaking such a task. Now all that is required is the availability of the funds to enable such administration, and the lawyers to provide their pro bono services.

Pro bono work is not charity. It is a natural incident of being a member of the legal profession. While failing to undertake such work may not be grounds for removal from the roll, it does show a lack of commitment or loyalty to the very system upon which the lawyer relies for livelihood.

45 For a more detailed analysis of these problems and proposed solutions see above $\mathrm{n} 37$.

46 The official commentary to rule 6.1 of the ABA Model Rules endorses such practices. See above $n$ 36. 